$$
\text { Conf-9405283--1 }
$$

DOE/METC/C-95/7165

Small-Scale AFBC-Hot Air Gas Turbine Power Cycle

Authors:

Robert C. Ashworth (Energy and Environmental Research Corporation)

Harold M. Keener (The Ohio State University)

Arthur W. Hall (METC)

Conference Title:

13th International Fluidized-Bed Combustion Conference

Conference Location:

Orlando, Florida

Conference Dates:

May 7-10, 1994

Conference Sponsor:

American Society of Mechanical Engineers (ASME) 


\section{DISCLAIMER}

This report was prepared as an account of work sponsored by an agency of the United States Government. Neither the United States Government nor any agency thereof, nor any of their employees, makes any warranty, express or implied, or assumes any legal liability or responsibility for the accuracy, completeness, or usefulness of any information, apparatus, product, or process disclosed, or represents that its use would not infringe privately owned rights. Reference herein to any specific commercial product, process, or service by trade name, trademark, manufacturer, or otherwise does not necessarily constitute or imply its endorsement, recommendation, or favoring by the United States Government or any agency thereof. The views and opinions of authors expressed herein do not necessarily state or reflect those of the United States Government or any agency thereof.

This report has been reproduced directly from the best available copy.

Available to DOE and DOE contractors from the Office of Scientific and Technical Information, 175 Oak Ridge Turnpike, Oak Ridge, TN 37831; prices available at (615) 576-8401.

Available to the public from the National Technical Information Service, U.S. Department of Commerce, 5285 Port Royal Road, Springfield, VA 22161; phone orders accepted at (703) $487-4650$. 


\section{DISCLAIMER}

Portions of this document may be illegible in electronic image products. Images are produced from the best available original document. 


\title{
SMALL-SCALE AFBC HOT AIR GAS TURBINE POWER CYCLE
}

\author{
Robert A. Ashworth \\ Energy and Environmental Research Corporation \\ Orrville, Ohio \\ Harold M. Keener \\ The Ohio State University \\ Ohio Agricultural Research and Development Center \\ Wooster, Ohio
}

\author{
Arthur W. Hall \\ U.S. Department of Energy \\ Morgantown Energy Technology Center \\ Morgantown, West Virginia
}

\begin{abstract}
The Energy and Environmental Research Corporation (EER), the Ohio Agricultural Research and Development Center (OARDC), the Will-Burt Company (W-B) and the U.S. Department of Energy (DOE) have successfully developed and completed pilot plant tests on a small scale atmospheric fluidized bed combustion (AFBC) system. This system can be used to generate electricity, and/or hot water, steam. Following successful pilot plant operation, commercial demonstration will take place at Cedar Lane Farms (CLF), near Wooster, Ohio. The system demonstration will be completed by the end of 1995. The project is being funded through a cooperative effort between the DOE, EER, W-B, OARDC, CLF and the Ohio Coal Development Office (OCDO).

The small scale AFBC, has no internal heat transfer surfaces in the fluid bed proper. Combining the combustor with a hot air gas turbine (HAGT) for electrical power generation, can give a relatively high overall system thermal efficiency. Using a novel method of recovering waste heat from the gas turbine, a gross heat rate of $13,500 \mathrm{Btu} / \mathrm{kWhr}(\sim 25 \%$ efficiency) can be achieved for a small $1.5 \mathrm{MW}$. plant. A low technology industrial recuperation type gas turbine is used that operates with an inlet blade temperature of $1450^{\circ} \mathrm{F}$ and a compression ratio of 3.9:1. The AFBC-HAGT technology can be used to generate power for remote rural communities to replace diesel generators, or can be used for small industrial co-generation applications.
\end{abstract}

\section{INTRODUCTION}

A small scale coal fired atmospheric fluidized bed combustion system has been tested at the pilot scale and is currently being demonstrated at a commercial nursery in Wooster, Ohio. These types of systems may be designed in sizes from 1.5 to 75 million Btu/hr. Agriculturalforestry waste, and waste oil may also be fired separately or co-fired with coal.

Most small fluidized bed combustion systems use in-bed heat transfer tubes to generate saturated steam, which can then be superheated and fed to a steam turbine for electric power generation, as shown by Ashworth (1994).

The AFBC being developed has no internal heat transfer surfaces. It can be combined with an indirect fired air heater, integrated with an industrial recuperated gas turbine, to yield a more efficient power plant than that possible with relatively simple Rankine steam cycles. Small FBC power plants, using saturated steam cycles for power generation have overall thermal efficiencies of 10 to $12 \%$.

The AFBC-HAGT power cycle can reach efficiencies up to $25+\%$. Such a cycle is ideally suited for rural communities, such as exist in Alaska, Canada, China, etc. that are not tied into an electrical power grid. It is also applicable for use in small industrial-commercial-institutional applications to provide electrical power plus waste heat that can be used for space heating or process applications. In remote locations, where water scarce, the system can be designed to generate electricity without the need for water. 


\section{ENVIRONMENTAL REGULATIONS}

From a pollution perspective, the small AFBCHAGT power plants must comply with EPA 40 CFR Part 60, "Standards of Performance for New Stationary Sources: Small Industrial-CommercialInstitutional Steam Generating Units; Final Rule (Federal Register, September 12, 1990)". Affected facilities are steam generating units for which construction, modification, or reconstruction has commenced after June 9,1989 , that have a maximum design heat input of 100 million Btu/hr or less, but greater than or equal to 10 million Btu/hr. Regulation highlights are as follows:

- For coal fired steam generating units with greater than 10 million Btu/hr but less than 75 million Btu/hr heat input capacity, the standards limit $\mathrm{SO}_{2}$ emissions to $1.2 \mathrm{lb} / \mathrm{MM}$ Btu coal fired.

-

For coal fired steam generating units with heat input capacities greater than 30 million $\mathrm{Btu} / \mathrm{hr}$, the standards limit particulate matter to $0.05 \mathrm{lb} / \mathrm{MM}$ Btu of coal fired and limit opacity to $20 \%$.

- There are no standards promulgated for $\mathrm{NO}_{\mathrm{x}}$ for coal fired steam generating units with heat input capacities of $100 \mathrm{MM}$ Btu/hr and less.

Under water and solid waste standards, no significant water pollution impacts are projected. Further, the projected impacts on solid waste generation are small. In addition, the wastes produced by particulate matter control processes are nonhazardous and can be disposed of using traditional treatment and disposal techniques.

\section{AFBC DEVELOPMENT}

A 1.5 Million Btu/hr AFBC pilot unit was designed, installed and started up at the OARDC in Wooster Ohio, in mid-1992. Over 100 operational runs were completed since startup through the end of 1993 (no electrical power was generated). The AFBC with no internal heat transfer surfaces was configured with flue gas recycle to control bed temperature. Sand was used as the fluidized bed media. The pilot combustion system produced hot water, and proved its operability for small scale industrial-commercialinstitutional applications for process use and space heating. The flue gas recycle technique is applied in applications where hot water or steam is produced to increase the overall thermal efficiency of this particular AFBC system.

Two coals, an Ohio coal and an Alaska coal; and two limestones, a dolomitic limestone and a calcitic limestone, were tested in the pilot unit. The fuel and alkali sorbent feedstock properties are shown in Table 1.

TABLE 1. COAL AND SORBENTS TESTED

Coals:

Wayne Mine Coal - Bituminous

(3.3 wt\% S) Ohio Coal, HHV @ 12,600 Btu/lb

Little Tonzana Coal - Sub-Bituminous

(1.1 wt\% S) Alaska Coal, HHV @7,600 Btu/b

Sorbents:

National Lime and Stone

80 wt\% $\mathrm{CaCO}_{3}$ Calcitic Limestone

Ohio Lime Company

$54.5 \mathrm{wt} \% \mathrm{CaCO}_{3}$ Dolomitic Limestone

During testing, sulfur capture was as high as $88.6 \%$, yielding a flue gas emission rate of $0.59 \mathrm{lb}$ of $\mathrm{SO}_{2} / \mathrm{MM}$ Btu when firing high sulfur Ohio coal. This level was accomplished with a dolomitic limestone being fed at a rate to yield a Ca/S ratio of 4.26 . The ratio includes the coal ash alkali components $(\mathrm{Ca}$, $\mathrm{Na}, \mathrm{K}$ ). Test results indicated that the regulated emission level of $1.2 \mathrm{lb}$ of $\mathrm{SO}_{2} / \mathrm{MM}$ Btu of coal fired can be met by using dolomitic limestone at a rate to yield a Ca/S ratio of 2.5 to 3.0 , see Figure 1. A sorbent recycle system was not included in the pilot testing; however, this technique will be used during the commercial demonstration at Wooster, Ohio.

The recycle technique should improve sorbent utilization, as found by Smith (1979) and Moulton (1989). By recycling large sorbent particles back into the fluidized bed of sand, the particles will be attrited and expose more unreacted sorbent for reaction with $\mathrm{SO}_{2}$. The $\mathrm{CaO}+1 / 2 \mathrm{O}_{2}+\mathrm{SO}_{2} \rightarrow \mathrm{CaSO}_{4}$ reaction as described by Hsieh (1975), is primarily a surface reaction, so sorbent particle attrition will expose unreacted calcium to improve calcium utilization.

Whereas the dolomitic limestone performed better than the calcitic limestone for the capture of $\mathrm{SO}_{2}$ based on calcium utilization, on a weight ratio (pounds limestone/pounds $\mathrm{SO}_{2}$ removed), both limestones performed similarly. This is because the calcitic limestone has a higher percentage of calcium carbonate than the dolomitic limestone. When selecting a limestone, the best option will be the lowest cost limestone. 


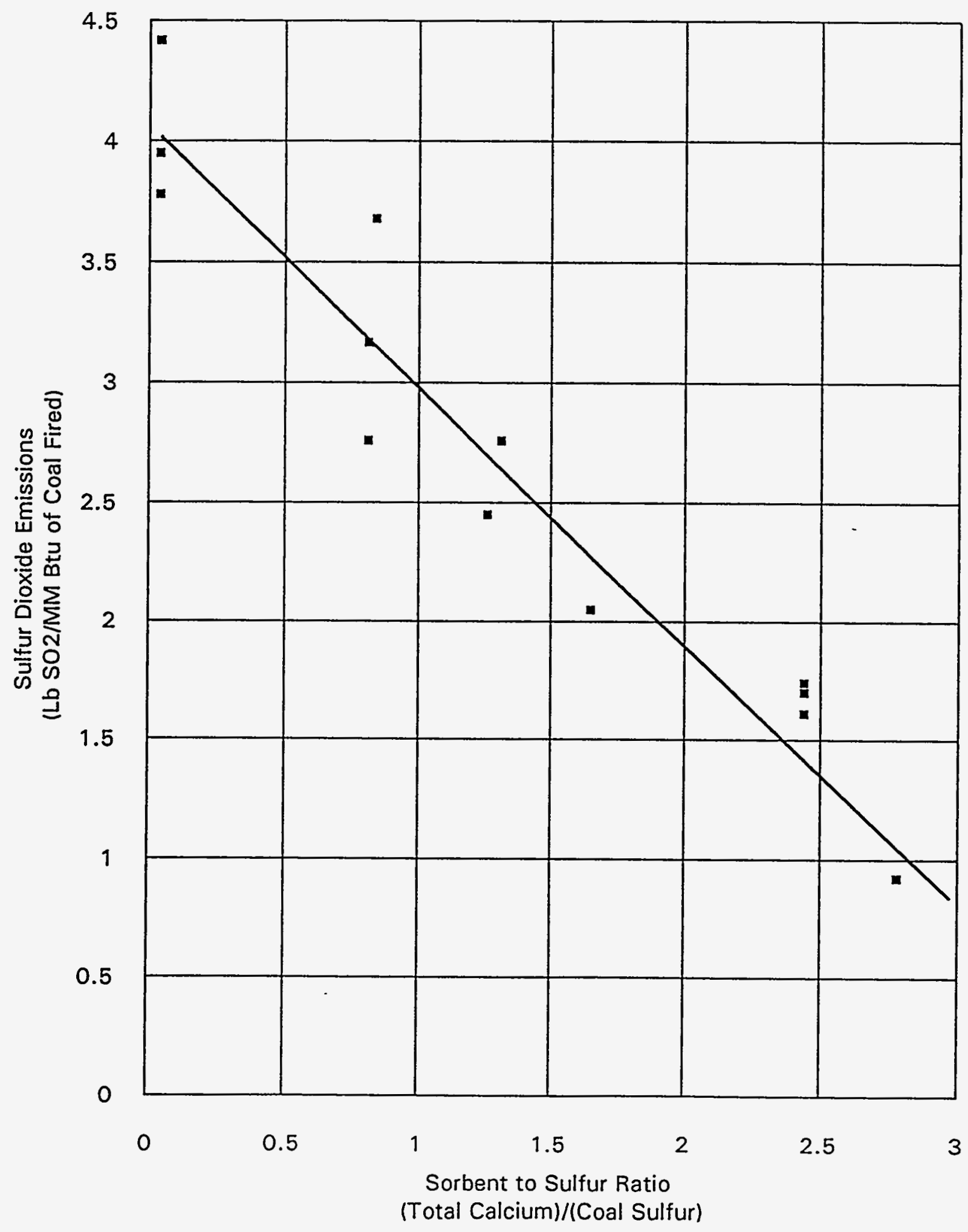

Figure 1. Sulfur dioxide emissions using a dolomitic limestone 
The pilot testing confirmed the results of Gaglia (1987) that showed that regardless of limestone type, the smaller the particle size, the greater the calcium utilization. The calcium utilization when using a $6 \times 16$ mesh limestone sorbent was $24 \%$ and for the $20 \times 80$ mesh size range was $30 \%$. Since silica sand is used as a bed media, rather than limestone, as used in some fluid bed systems, the size of the limestone is not critical to the sand bed fluidization characteristics. Therefore, this system can take advantage of a smaller size limestone to achieve a higher calcium utilization.

No limestone was fed into the combustor during the testing of the Little Tonzana Alaskan coal; however, the alkali components $(\mathrm{Ca}, \mathrm{Na}, \mathrm{K})$ in the coal ash yielded an alkali/S ratio of 1.19. The Alaska coal sulfur would be expected to produce an $\mathrm{SO}_{2}$ emission rate of $2.78 \mathrm{Lb} / \mathrm{MM}$ Btu of coal fired. As a result of the alkali in the ash capturing sulfur, the $\mathrm{SO}_{2}$ emissions to the atmosphere was only 1.33 $\mathrm{lb} / \mathrm{MM}$ Btu of coal fired, a fifty-two percent reduction.

Fluidized bed combustion systems are noted for their low $\mathrm{NO}_{\mathrm{x}}$ emissions; however the reason for the low level has not been clearly defined. It is known that the low temperature of the bed should reduce formation of thermal $\mathrm{NO}_{\mathbf{x}}$. It is also theorized that the air-fuel mixing in the bed may yield reducing species to convert nitrogen oxides to diatomic nitrogen.

During the testing of this particular AFBC it was possible, by controlling the flue gas recycle rate to change the flue gas exit oxygen concentration. At flue gas exit oxygen concentrations of 10 vol\% and higher, the carbon monoxide concentration in the flue gas was usually less than $100 \mathrm{ppmv}$. At these carbon monoxide levels, $\mathrm{NO}_{x}$ emissions were fairly high, 0.8 to $1.0 \mathrm{lb} \mathrm{NO} / \mathrm{MM} \mathrm{Btu}$, when firing Ohio bituminous coal. However, as the flue gas recycle was increased, and the oxygen level reduced to $8 \%$ and less, the carbon monoxide concentration increased. When it reached $\sim 200 \mathrm{ppmv}$, as shown in Figure 2, the $\mathrm{NO}_{x}$ emissions dropped below 0.40 $\mathrm{lb} / \mathrm{MM}$ Btu. The Ohio coal tested had a nitrogen content of 1.2 wt\%. When firing the Alaska coal, which had a nitrogen content of 0.48 wt $\%$, the dramatic effect of reduced $\mathrm{NO}_{x}$ emissions with increasing $\mathrm{CO}$ was not observed.

Nonetheless, the carbon monoxide effect when firing the higher nitrogen content coal was very intriguing. To assess this phenomena, theoretical equilibrium coefficients were calculated for the following reaction over the fluidized bed operating temperature range:

$$
\mathrm{CO}+2 \mathrm{NO}=\mathrm{N}_{2}+\mathrm{CO}_{2}
$$

The theoretical equilibrium coefficients, $\log \mathrm{Kp}$, are shown in Figure 3 comparing the theoretical with the actual coefficients calculated from run data for both the Ohio and Alaska coals. As presented, it is seen that the actual equilibrium coefficient (average $\mathrm{Kp}=$ $1.4 \times 10^{11}$ ) is fairly flat over the temperature range studied. This correlation provides fairly convincing evidence that the low $\mathrm{NO}_{x}$ emissions from fluidized bed combustion systems are directly related to bed CO concentration.

Another interesting facet of this AFBC system is that the only point that ash and spent sorbent exit the system is from the baghouse. During pilot plant operations, it was seen that there was no ash/ sorbent buildup in the combustor proper. This was true for the Ohio bituminous coal and the Alaska sub-bituminous coal for over 100 runs. This feature provides increased operator safety and also simplifies the operation of the system. No hot bed material is required to be removed from the AFBC, only relatively cool flyash and spent sorbent. $A$ flanged entry is provided to remove clinkers, but todate no clinkering has occurred. The calcined fly ash will be tested for use as a fertilizer and soil conditioner.

The AFBC has successfully demonstrated the firing of coal, with a particle size of $1^{\prime \prime} \times 0^{\prime \prime}$. Simple grinding of run-of-mine coal is all that is required to prepare the feed for introduction into the AFBC. Coal washing is not required and the AFBC system can process coals with very high ash content (up to $50 \%$ ). An inert bed material such as sand or crushed refractory may be used as the fluid bed heat transfer media. Limestone may be fed with the coal to act as a sorbent to reduce $\mathrm{SO}_{2}$ emissions.

The system is designed with simplicity as the prime input. It is recognized that small scale operators will not have the resources to maintain the large staff necessary to operate and maintain a complex fluidized bed combustion system. The combustor is a refractory lined vessel that operates under a slightly negative pressure $\left(-0.2^{\prime \prime} \mathrm{WC}\right)$. The only -maintenance requirements are periodic refractory repair and possibly grid plate repair.

\section{AFBC-HAGT SYSTEM}

The AFBC-HAGT system for electrical power generation will use the AFBC design used in the Cedar Lane Farms commercial demonstration. The flue gas to air heat exchanger is state-of-the-art technology which may be supplied by several heat exchanger manufacturers. Commercially available low technology industrial recuperated gas turbines 


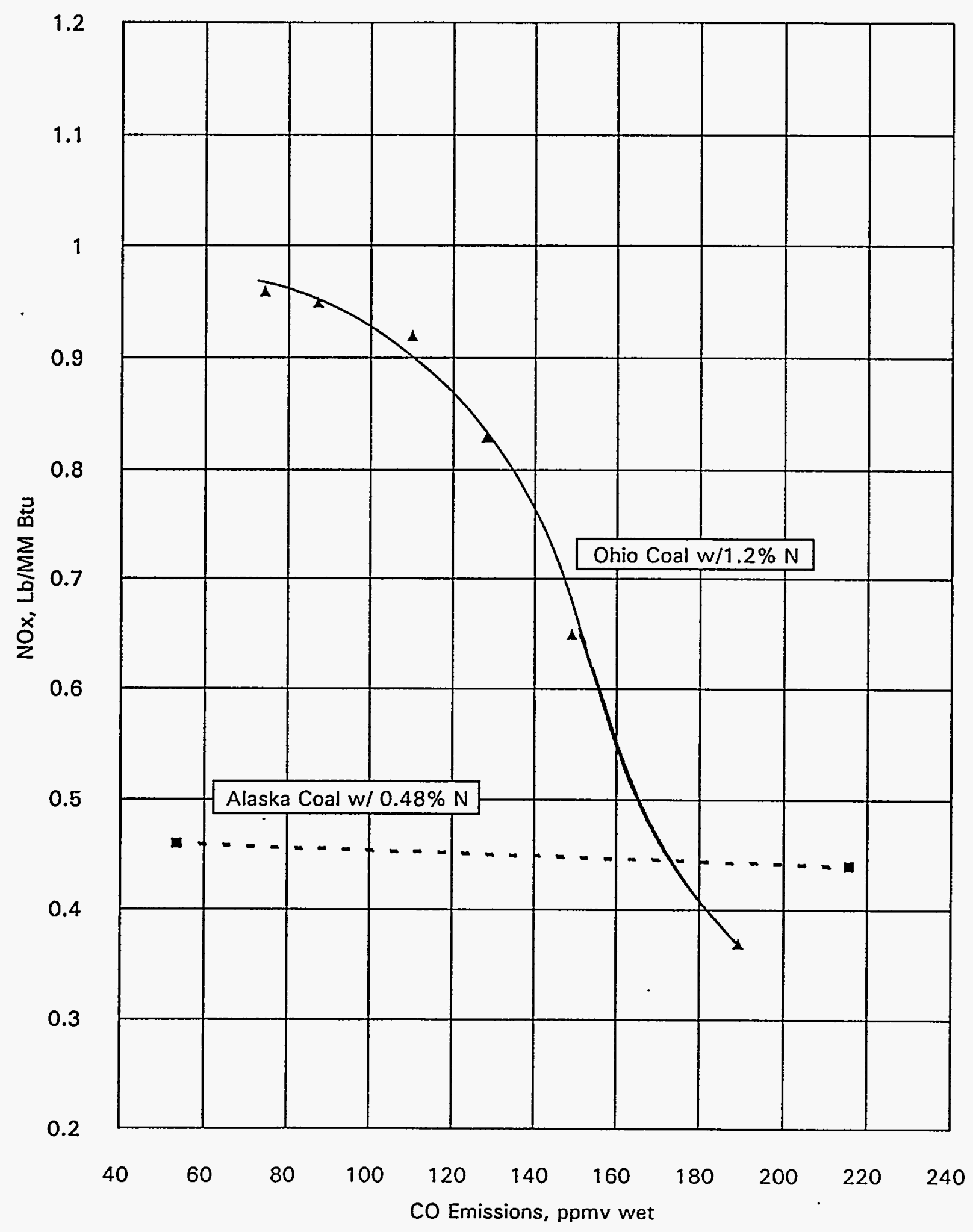

Figure 2. NOx as a function of carbon monoxide concentration 


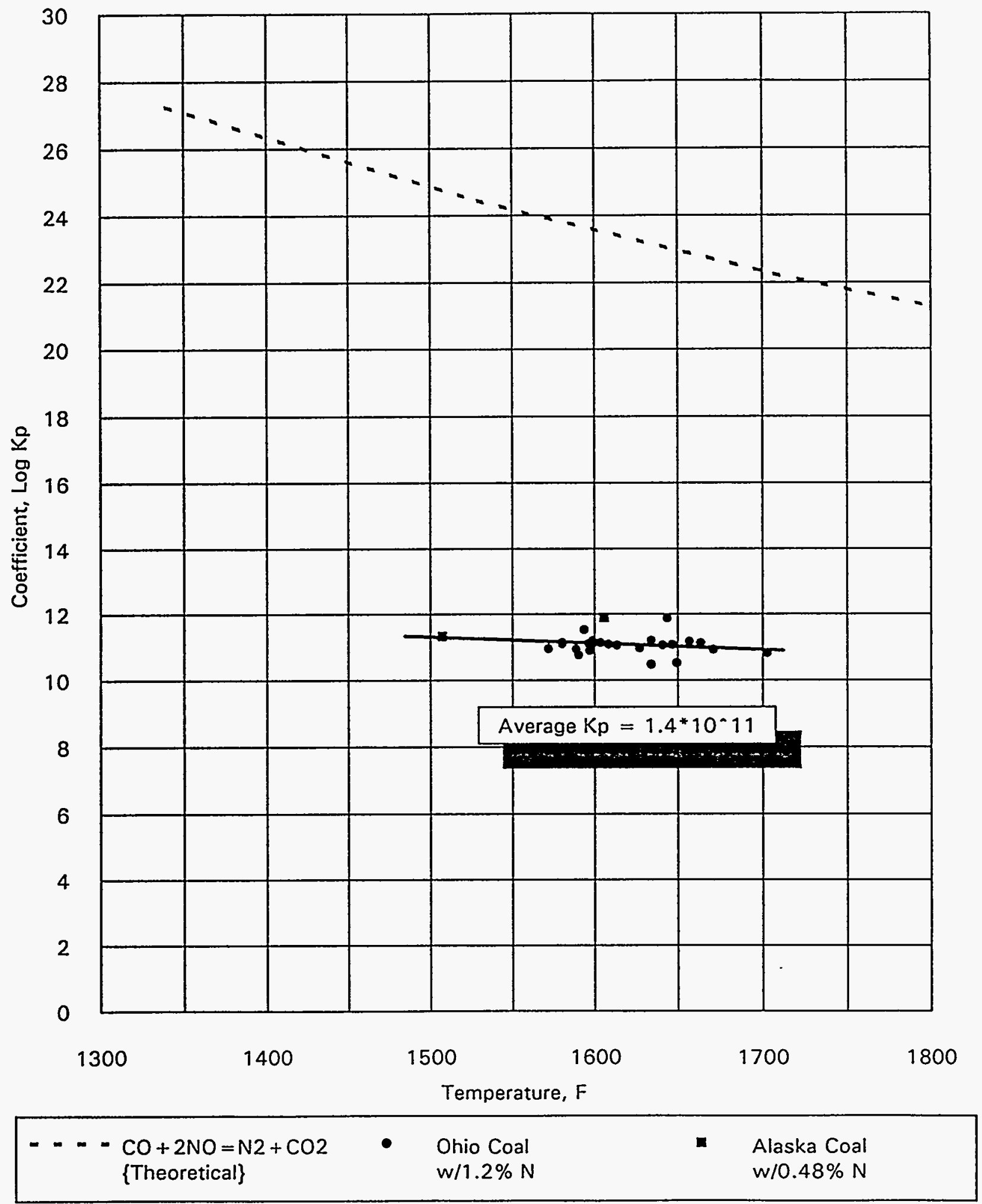

Figure 3. CO-NOx reducing reaction equilibria in AFBC 
will also be used. Although the AFBC-HAGT system has not been demonstrated as an integrated cycle, by the end of the demonstration program at Cedar Lane Farms, many of the component parts will have been demonstrated at the commercial level. After startup and successful operation of the AFBC at Cedar Lane Farms, a commercial demonstration of the small scale AFBC-HAGT power cycle will be investigated.

AFBC-HAGT Application. The State of Alaska is interested in the use of coal to replace diesel fuel in rural communities for three important reasons: 1) many existing diesel fuel storage tanks in these communities are leaking and the environmental cleanup is going to be costly, 2) the State would rather use indigenous coal mined by local labor than import diesel fuel, and 3) the State would like to reduce its power cost equalization subsidies. Rural Alaskan villages will have an interest in small scale coal fired power plants, if they are economically attractive compared to diesel-fired electrical power generation.

An investigation of applying the AFBC-HAGT system for power generation was made for the Village of St. Paul, Alaska. St. Paul Village is on St. Paul Island, an island in the Pribilof Island group located in the Bering Sea, approximately 750 miles west of Anchorage. The Village has a permanent population of 600 that increases to approximately 750 during the crab and fish season when temporary labor is brought in to assist with seafood processing. The island covers an area of about 35 square miles.

The existing power generation facility has five operational diesel fuel powered generators, with output capacities of $865 \mathrm{kWe}, 545 \mathrm{kWe}, 300 \mathrm{kWe}$ and 2 units @ $210 \mathrm{kWe}$ each. The five 480 volt, 60 cycle generators tie into a common bus for a $12,470 / 7,200$ voltage distribution to the Village. The conceptual plant design was developed based on the site conditions and requirements listed below:

\section{Design Basis}

- Climate: Elevation $=\sim 20 \mathrm{ft}$. above sea level; Temperature $=25^{\circ} \mathrm{F}$ winter to $50^{\circ} \mathrm{F}$ in summer

- Labor Cost: Operating Labor @ \$20/hr; Construction Labor, 80\% Local @ \$15/hr 20\% Imported@\$45-\$85/hr + \$150 per diem
- Current Cost of Electricity: (Diesel based power) $\$ 0.34 / \mathrm{kWhr}$, residents pay $\$ 0.19 / \mathrm{kWhr}$ as per the Alaska Energy Authority (1991) Power cost equalization subsidy $=\$ 0.15 / \mathrm{kWhr}$

- Current Electric Power Consumption: Range $900 \mathrm{kWe}$ to $1800 \mathrm{kWe}$

- Electric Power Design Basis for AFBC: Nominally $1500 \mathrm{kWe}$ maximum

- Site for AFBC: Located next to dock, see Figure 4, 2 acres owned by City @ \$0/acre

- Limestone Supply: Sulfur in Evan Jones coal is low enough so that limestone will not be required to meet the regulated $1.2 \mathrm{lb} \mathrm{SO}_{2} / \mathrm{MM}$ Btu of coal fired.

- Coal Supply: Evan Jones Coal Mine, in Sutton, AK, see Table 2. Delivered coal cost to St. Paul at $\$ 82.00$ ton (FOB St. Paul). Price was provided by the Arctic Slope Consulting Group.

AFBC-HAGT Power Plant. Coal is delivered by barge to the island where it is unloaded and transported to a coal pile. From the coal pile the coal is transported to a receiving hopper. Coal from the hopper is then fed into a small crusher to reduce the coal to a minus 1 inch size, see Figure 5, and is then conveyed to a coal bin. From the bin, the coal is fed to two 12' I.D. fluidized bed combustors. The total coal feed rate, equally divided between the combustors, is approximately $850 \mathrm{lb} / \mathrm{hr}$. The coal feed rate is controlled to maintain the fluidized bed of sand at a temperature of $1550^{\circ} \mathrm{F}$.

Coal augers feed into two pneumatic eductors that transport the fuel into the bottom of each fluidized bed. A slip stream of air from the turbine exhaust is used as the carrier media. The coal is fed into a bed of sand being fluidized by the hot air exhaust from the gas turbine expander. Sulfur removal is not required with the Evan Jones coal. However, limestone would be added to the bed for coals with sulfur contents that exceed the regulatory limit of 1.2 Ib SO2/MM Btu of coal fired. Startup of the gas turbine will be accomplished by firing diesel fuel into a pressurized startup combustor that exhausts into the inlet piping to the gas turbine.

The hot gas streams from both combustors are combined, and the $1550^{\circ} \mathrm{F}$ flue gas enters one flue gas/hot air heat exchanger. Air from the gas turbine 


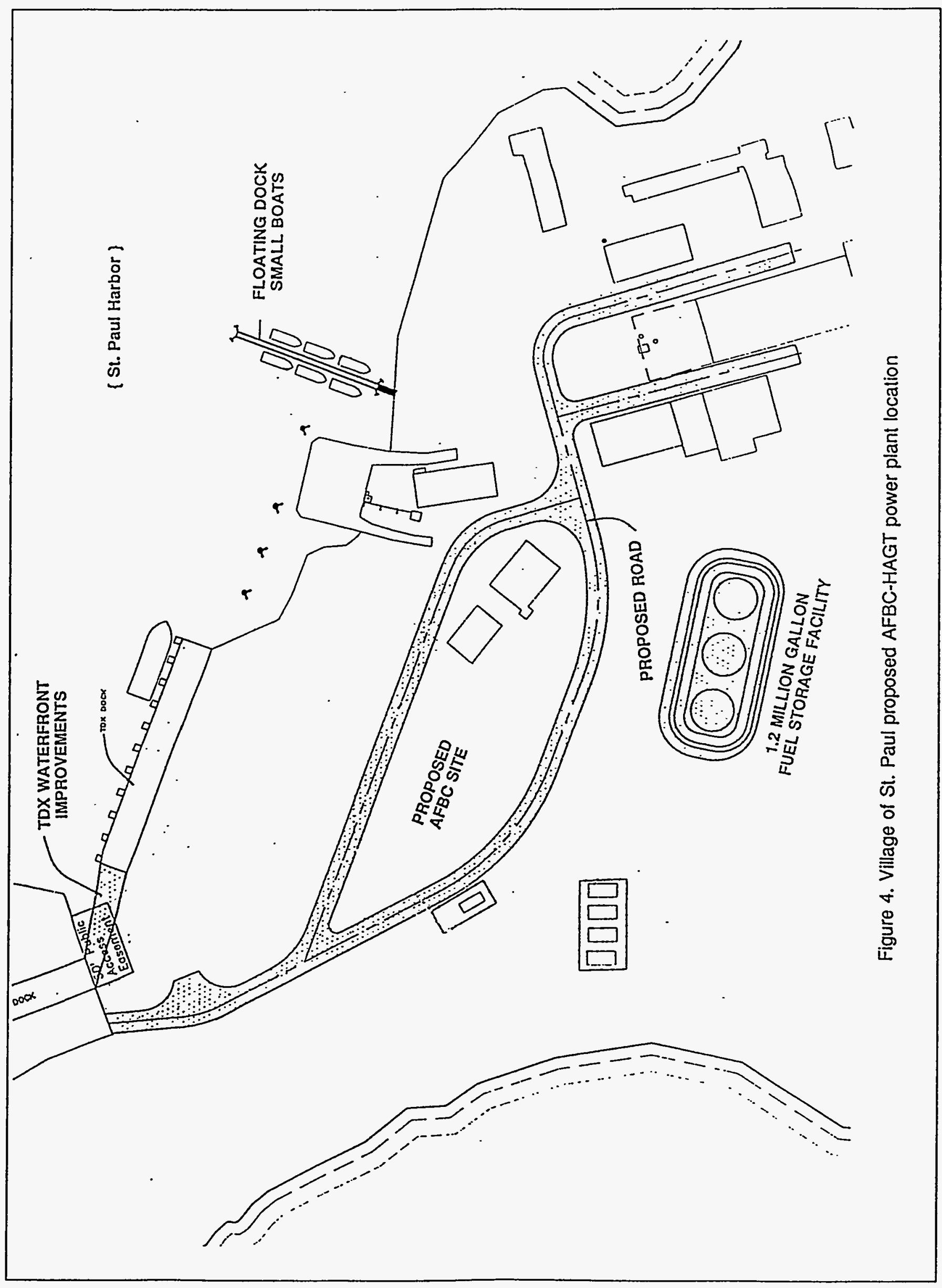




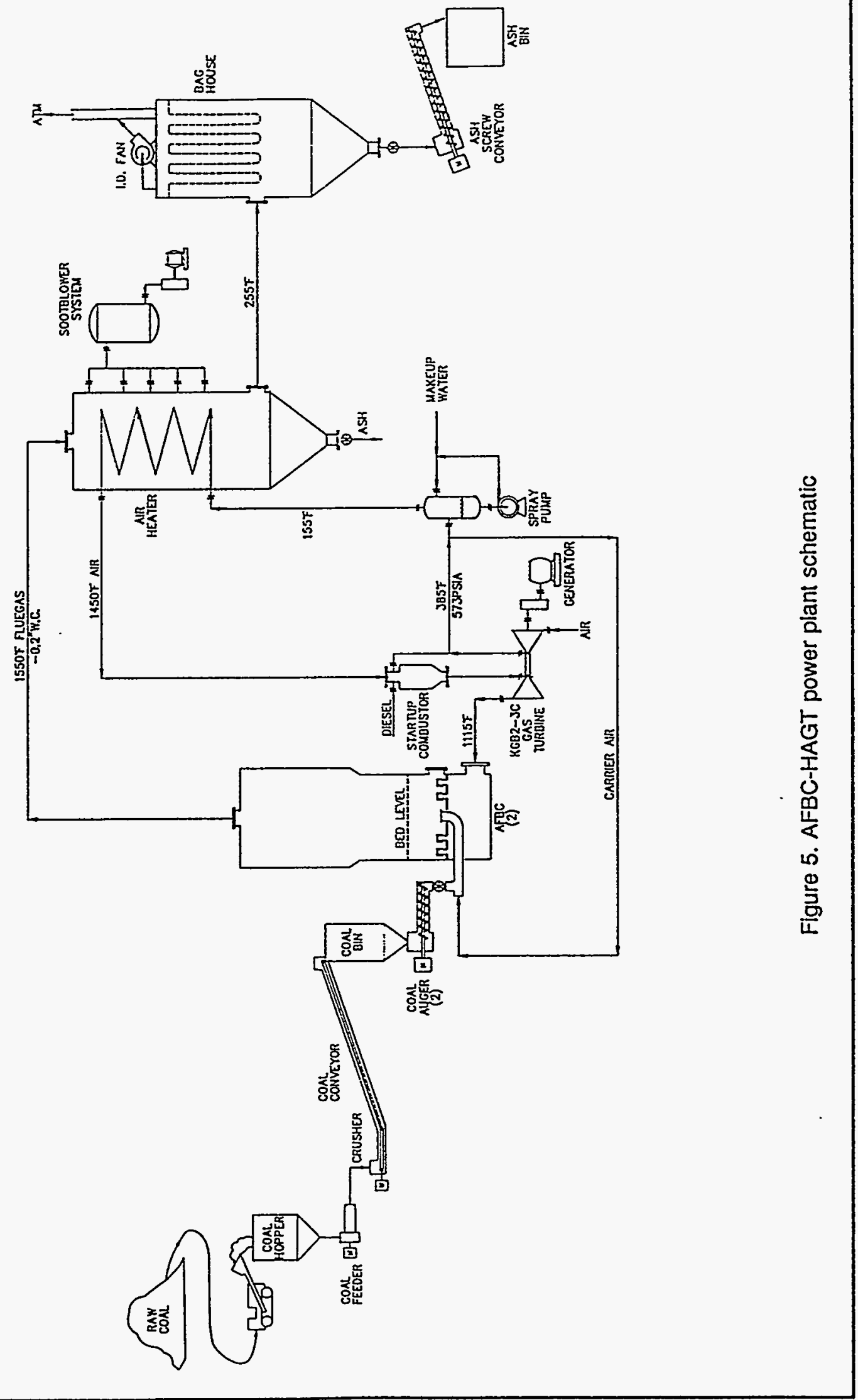


compressor, at $385^{\circ} \mathrm{F}$, enters a saturator where softened water $(\sim 10.7 \mathrm{gpm})$ is sprayed into the air stream to bring the temperature down to its water saturation point $\left(\sim 155^{\circ} \mathrm{F}\right)$. The hot flue gas flows through the shellside of the heat exchanger, heating the compressed air (tubeside) from the air saturator. The air humidification technique as described by Fluor Daniel (1991) is applied to increase the overall thermal efficiency of the gas turbine power cycle.

The heat exchanger is an economical design that uses carbon steel for temperatures below $750^{\circ} \mathrm{F}, 21 / 4$ $\mathrm{Cr}-1$ Mo alloy for temperatures between $750^{\circ} \mathrm{F}$ and $1150^{\circ} \mathrm{F}$, and type 304 ss for temperatures above $1150^{\circ} \mathrm{F}$. All of the tubes are finned, and since there is particulate in the flue gas, a sootblower system is integrated into the operation of the exchanger. The air pressure drop through the tubes is approximately $3 \mathrm{psi}$, and the flue gas pressure drop through the shell is $2 "$ WC.

The pressurized hot air from the heat exchanger, at $1454^{\circ} \mathrm{F}$, enters an industrial recuperated gas turbine expander that is nominally rated at $1.5 \mathrm{MWe}$. It is necessary for this system to use a recuperated gas turbine, because it incorporates piping to and from a recuperator. The recuperator, in this case, is replaced by the flue gas/air heat exchanger.

The gas turbine operates at a 3.9:1 compression ratio with a maximum turbine expander inlet temperature of $1500^{\circ} \mathrm{F}$. The work done by the hot gas expansion through the turbine supplies power to compress air and generate electricity. The particular turbine selected has air compression and expansion isentropic efficiencies of $68.4 \%$ and $74.6 \%$, respectively. The turbine that was selected was a reco'nditioned recuperated gas turbine available through Dresser-Rand. It was chosen to reduce capital cost. Several used recuperated gas turbines were available when the study was completed.

The flue gas recycle technique is not used in the AFBC-HAGT cycle; with this cycle the overall thermal efficiency would be reduced compared to a once through hot air system. The reason for this is that flue gas recycle would reduce the mass flow rate through the turbine, and the lower mass flow rate, the lower the overall thermal efficiency of the system.

The hot air exiting the expansion turbine at $1115^{\circ} \mathrm{F}$ enters the AFBC windbox to supply hot air for coal combustion and fluidization of the bed. Temperature control in the fluid bed is maintained by controlling the coal feed rate. A patent on this system has been applied for based on the unique feature of using the hot turbine exhaust as the fluidizing/ combustion air. By introducing the hot turbine exhaust into the fluid bed, less coal is required to bring the bed up to operating temperature and the net result is increased overall thermal efficiency.

Two power generation options are available with this system; 1) generation of electricity only and 2) generation of electricity plus steam or hot water. The first option is the more efficient method for generating electricity. With this option, water is sprayed into the hot air exiting the turbine compressor prior to entering the flue gas/air heat exchanger. The water rate is set to saturate the air stream, thus providing more mass to the turbine expander with the end result of producing more electricity compared to the use of air only.

In addition, the cooling of the air results in a reduction of flue gas temperature exiting the heat exchanger, thus less sensible heat is exhausted to the atmosphere. With the water spray option, the flue gas from the flue gas/air heat exchanger is drawn through a baghouse with an induced draft fan and is vented through a stack to the atmosphere.

With the second option, which does not use an air saturator, the flue gas exiting the heat exchanger is hotter than the case where humidification of air is added. Because of this, a waste heat recovery unit may be added for producing hot water or steam. The heat exchanger may be added at the exit of the air heater, prior to the baghouse.

Thermal Efficiency. Based on the plant description for the St. Paul application, mass and energy balances were developed for the system to determine its thermal efficiency. The overall mass and energy balance is shown in Table 3. The St. Paul AFBC-HAGT power plant would yield a gross electrical output of $1473 \mathrm{KWe}$, a net of $1396 \mathrm{kWe}$. The gross and net heat rates were calculated to be $13,495 \mathrm{Btu} / \mathrm{kWhr}$ and $14,245 \mathrm{Btu} / \mathrm{kWhr}$, respectively. The attractiveness of the AFBC-HAGT system is that relatively high thermal efficiencies can be realized for small scale power plants.

These small scale power plants can be designed to cover an electrical output range of $25 \mathrm{kWe}$ to 5 MWe. The AFBC-HAGT design, for units covering the range of $75 \mathrm{kWe}$ to $5 \mathrm{MWe}$, would be constructed in accord with the design described. However, for the smaller $25 \mathrm{kWe}$ to $75 \mathrm{kWe}$ units, a more simple and economical fluidized bed combustor that includes certain techniques described by Henry (1984) and Keener (1989), and incorporates a concentric annular air heat exchanger around the fluid bed, could best be applied. The 
AFBC-HAGT system is very flexible and can be tailored to meet the power and district heat requirements of a rural community or an industrialcommercial-institutional facility.

Environmental Considerations The small scale AFBC-HAGT power plants would have a fuel heat input of 75 million Btu/hr or less; therefore, the only Federal air emission regulations that apply concern particulate and sulfur dioxide emissions. The system will include a baghouse for particulate control and limestone injection, if required, for sulfur dioxide emission control. A typical baghouse can easily meet the particulate emission limits imposed on these small units. The only environmentally related question for each AFBC-HAGT, is how much limestone is required, for a particular coal feed, to control the sulfur dioxide emissions to the regulatory limit of 1.2 Lb/MM Btu.

Economic Analysis. An economic analysis was completed to provide electrical power for sale to the Village of St. Paul. Capital costs were developed based on equipment costs and the use of labor construction rates in St. Paul. Table 4 shows the projected capital and operating costs. It also shows the basis for the economic analysis. The capital cost was estimated at $\$ 4.38 \mathrm{MM}(\$ 3,138 / \mathrm{kWe}$ sold). The operating costs were based on the quoted delivered coal cost and operating labor cost in the Village. The annual operating costs for the AFBC-HAGT were projected to be $\$ 1.23 \mathrm{MM}$.

Discounted cash flow, rates of return on investment were developed, and the sensitivity of the price of electricity to return on investment was analyzed. The results of this analysis are shown in Figure 6. To satisfy an $8 \%$ DCF-ROI, the required selling price of electricity, with $\$ 82 /$ ton ( $\$ 4 / \mathrm{MM} \mathrm{Btu)}$ delivered coal, was calculated at $17 \varnothing / \mathrm{kWhr}$.

The current price of diesel fuel delivered to St. Paul for power generation is $\$ 1.37 /$ gallon or approximately $\$ 10 / \mathrm{MM}$ Btu. The selling price of electricity in St. Paul is $34 \phi / \mathrm{kWhr}$ with an operating cost (including fuel) that makes up $18.7 \mathrm{c} / \mathrm{kWhr}$ of the total. This compares with an operating cost (including fuel) for the AFBC-HAGT power plant of $11.9 \% / \mathrm{kWhr}$. From the analyses completed, the small scale AFBC-HAGT power cycle appears as an economical alternative to diesel power generation for the rural Alaskan community of St. Paul.

\section{REFERENCES}

Alaska Energy Authority, "Statistical Report of the Power Cost Equalization Program, Fourth Edition, Fiscal Year 1991.

Ashworth, R. A., Frato, R. L., 1994, "Northwest Arctic Coal Development Combustion Technology Study", Technical/Regulatory Report, State of Alaska, Department of Community and Regional Affairs, Division of Energy.

Fluor Daniel, 1991, "A Comparison of Humid Air Turbine (HAT) Cycle and Combined-Cycle Power Plants," EPRI Technical Report IE-7300.

Gaglia, B. N., Hall, A. W., 1987, "Comparison of Bubbling and Circulating Fluidized Bed Industrial Steam Generation", presented at the 9th International FBC Conference, Boston, MA.

Henry, J. E., Keener, H. M., Anderson, R. J., 1984, "Adapting a Biomass Fluidized Bed Combustor for Operating a Hot Gas Turbine", presented at the Winter Meeting of the ASAE, New Orleans, LA.

Hsieh, B. C., Ashworth, R. A., Switzer, G. W., 1975, "An Analysis of Chemistry and Mechanisms for High Temperature Desulfurization of Low Btu Gas when using Lime or Limestone", Technical Report, Office of Coal Research, U.S. Department of the Interior, Contract No. 14-32-001-1236.

Keener, H. M., 1989, "Design of a $0.3 \mathrm{MW}$ Atmospheric Fluidized Bed Combustor with a Concentric Air Heat Exchanger", reprinted from the Transactions of the ASAE (Vol. 32, No. 2, pp 403407).

Moulton, D. S., 1989, "Recycle of Fluidized-Bed Combustion Bed-Drain Material to Reduce Waste Volume", EPRI Agreement RP2120-65 Final Report.

Smith, J. W., Bonk, D. L., Howe, W. C., 1979, "B\&W/EPRI Fluidized Bed Development Program", presented at the International Coal Utilization Conference and Exhibition, Houston, TX. 


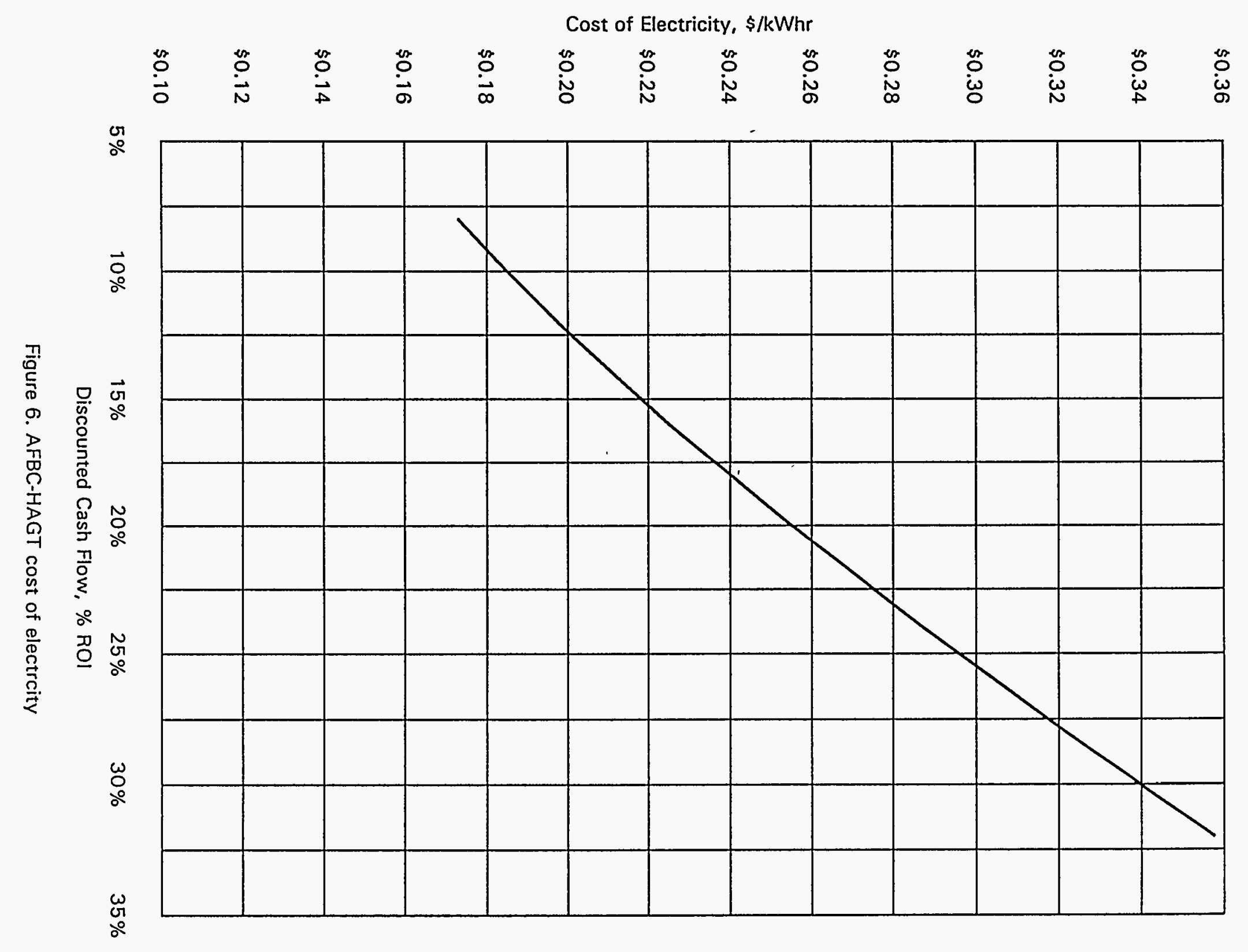


TABLE 2. EVAN JONES COAL ANALYSIS

(As Received High Volatile B Bituminous Coal)

$\begin{array}{lc}\text { Proximate: } & W t \% \\ \text { Fixed Carbon } & 43.44 \\ \text { Volatile Matter } & 38.76 \\ \text { Ash } & 13.05 \\ \text { Moisture } & 4.75 \\ \quad \text { Total } & 100.00 \\ & \\ \text { Ultimate: } & W t \% \\ \text { Carbon } & 65.94 \\ \text { Hydrogen } & 4.95 \\ \text { Oxygen } & 10.00 \\ \text { Nitrogen } & 1.00 \\ \text { Sulfur } & 0.31 \\ \text { Moisture } & 4.75 \\ \text { Ash } & 13.05 \\ \quad \text { Total } & 100.00\end{array}$

Higher Heating Value, HHV $=11,829 \mathrm{Btu} / \mathrm{lb}$

Coal Sulfur $=0.52 \mathrm{Lb} \mathrm{SO}_{2} / \mathrm{MM} \mathrm{Btu}$

TABLE 3. ST. PAUL AFBC-HAGT POWEER PLANT

OVERALL MASS AND ENERGY BALANCE

Basis: 14.7 psia, $60^{\circ} \mathrm{F}, \mathrm{H}_{2} \mathrm{O}$ as a liquid

Input:

Coal:

Heat of Combustion

Sensible Heat @ 40F

Water@ $50^{\circ} \mathrm{F}$

Air@ $90^{\circ} \mathrm{F}$

Total

$\frac{\mathrm{Lb} / \mathrm{hr}}{1,680}$

Btu/hr

Output:

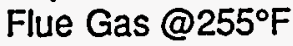

Particulate :

Heat of Combustion

Sensible Heat @225F

Electrical Power Output

Heat Loss:

Combustor

Air Heater

Bag House

Turbine

Total

\begin{tabular}{rr}
1,680 & $19,878,634$ \\
& $-16,002$ \\
5,350 & $-53,500$ \\
$\frac{106,200}{113,230}$ & $-153,680$ \\
\hline$\frac{\mathrm{L} / \mathrm{hr}}{19,655,452}$ & Btu/hr \\
\hline 113,005 & $12,388,972$ \\
225 & 93,654 \\
& 9,520 \\
& $5,027,964$ \\
& 807,199 \\
& $1,060,120$ \\
& 253,030 \\
& 14,993 \\
\hline \hline 113,230 & $19,655,452$
\end{tabular}

Thermal Efficiency; Gross $=25.3 \%$, Net $=24.0 \%$

Heat Rate; Gross $=13,495 \mathrm{Btu} / \mathrm{kWhr}$, Net $=14,245 \mathrm{Btu} / \mathrm{kWhr}$

Electrical Power Out; Gross $=1,473 \mathrm{kWe}$, Net Electricity for Sale $=1,396 \mathrm{kWe}$ 
TABLE 4. AFBC-HAGT ELECTRICAL POWER GENERATION

ST. PAUL, ALASKA

\section{CAPITAL COST}

Category:

Major Equipment

Instruments

Supplies

Building (incl. labor)

Construction Labor

Engineering

Freight/Taxes/Permits

Cost, $\$$

$2,050,000$

110,000

280,000

310,000

990,000

325,000

315,000

Total Plant Investment (TPI)

$\$ 4,380,000$

\section{OPERATING COST}

Raw Material:

Coal @ \$3.93 /MM Btu

Annual Use Cost/Unit

6,252 tons $\$ 82.00 /$ ton

Cost/Yr $\quad$ Cost/kWhr

Utilities:

Electricity

Treated Water

$573 \mathrm{MWhr}$

$\$ 0.00 / \mathrm{kWhr}$

$\$ 2.00 / \mathrm{Mgal}$

$\$ 512,655$

$\$ 0.049$

Ash Disposal:

774 tons

$\$ 10.00$ /ton

$\$ 0.001$

Labor:

Operating

8,760 mnhrs

$\$ 20.00 / \mathrm{mnhr}$

$\$ 175,200$

$\$ 0.017$

Maintenance $(60 \%$ of $3 \%$ of TPI)

Supervision ( $20 \%$ of O \& M labor)

$\$ 78,840$

$\$ 0.008$

$\$ 50,808$

$\$ 0.005$

Supplies:

Operating ( $30 \%$ of operating labor)

$\$ 52,560$

$\$ 0.005$

Maintenance $(40 \%$ of $3 \%$ of TPI)

$\$ 52,560$

$\$ 0.005$

Admin. and Gen. Ovhd. (60\% of total labor):

$\$ 182,909$

$\$ 0.018$

Insurance and Taxes (2.7\% of TPI):

$\$ 118.260$

$\$ 0.011$

Total Operating Cost

$\$ 1,231,689$

$\$ 0.119$

- Based on 310 days per year at stated capacity

BASIS FOR ECONOMIC ANALYSES

20 Year Project Life

15 Years Modified Accelerated Cost Recovery System on Total Plant Investment

$100 \%$ Equity Capital

Federal Taxes @ 34\% and State of Alaska Taxes@ @\% 